\title{
ATP-regulated potassium channels and voltage-gated calcium channels in pancreatic alpha and beta cells: similar functions but reciprocal effects on secretion
}

\author{
Patrik Rorsman • Reshma Ramracheya • \\ Nils J. G. Rorsman • Quan Zhang
}

Received: 16 January 2014 / Accepted: 25 April 2014 /Published online: 7 June 2014

(C) Springer-Verlag Berlin Heidelberg 2014

\begin{abstract}
Closure of ATP-regulated $\mathrm{K}^{+}$channels $\left(\mathrm{K}_{\mathrm{ATP}}\right.$ channels) plays a central role in glucose-stimulated insulin secretion in beta cells. $\mathrm{K}_{\mathrm{ATP}}$ channels are also highly expressed in glucagon-producing alpha cells, where their function remains unresolved. Under hypoglycaemic conditions, $\mathrm{K}_{\mathrm{ATP}}$ channels are open in alpha cells but their activity is low and only $\sim 1 \%$ of that in beta cells. Like beta cells, alpha cells respond to hyperglycaemia with $\mathrm{K}_{\mathrm{ATP}}$ channel closure, membrane depolarisation and stimulation of action potential firing. Yet, hyperglycaemia reciprocally regulates glucagon (inhibition) and insulin secretion (stimulation). Here we discuss how this conundrum can be resolved and how reduced $\mathrm{K}_{\mathrm{ATP}}$ channel activity, via membrane depolarisation, paradoxically reduces alpha cell $\mathrm{Ca}^{2+}$ entry and glucagon exocytosis. Finally, we consider whether the glucagon secretory defects associated with diabetes can be attributed to impaired $\mathrm{K}_{\mathrm{ATP}}$ channel regulation and discuss the potential for remedial pharmacological intervention using sulfonylureas.
\end{abstract}

Keywords $\mathrm{Ca}^{2+} \cdot$ Diabetes $\cdot$ Glucagon $\cdot \mathrm{K}_{\mathrm{ATP}}$ channel . Review $\cdot$ Sulfonylureas

$\begin{array}{ll}\text { Abbreviations } \\ {\left[\mathrm{Ca}^{2+}\right]_{\mathrm{i}}} & \text { Intracellular } \mathrm{Ca}^{2+} \text { concentration } \\ {[\mathrm{cAMP}]_{\mathrm{i}}} & \text { Intracellular cAMP concentration } \\ \text { FACS } & \text { Fluorescence-activated cell sorting } \\ \text { GCK } & \text { Glucokinase } \\ \mathrm{K}_{\text {ATP }} & \text { ATP-regulated } \mathrm{K}^{+} \text {(channel) }\end{array}$

P. Rorsman $(\bowtie) \cdot$ R. Ramracheya $\cdot$ N. J. G. Rorsman • Q. Zhang Radcliffe Department of Medicine, Oxford Centre for Diabetes, Endocrinology and Metabolism, University of Oxford, Oxford OX3 7LJ, UK

e-mail: patrik.rorsman@drl.ox.ac.uk
PKA Protein kinase A

SERCA Sarco-endoplasmic reticulum $\mathrm{Ca}^{2+}$-ATPase

\section{Introduction}

Glucagon, secreted by the pancreatic alpha cells of the pancreatic islets, is the body's principal hyperglycaemic hormone $[1,2]$. Together with insulin, glucagon ensures that plasma glucose levels are kept within a narrow range by accelerating hepatic glucose production via stimulation of glycogenolysis [3], regardless of eating, exercise and fasting [4]. Glucagon secretion is triggered by amino acids, fatty acids, neurotransmitters (such as adrenaline [epinephrine] and gastric inhibitory polypeptide [GIP]) [2], but a fall in plasma glucose levels arguably represents the physiologically most important physiological stimulus.

Interest in the regulation of glucagon secretion has been renewed by the recent rediscovery of the central role of glucagon in diabetes. Thus, over-secretion of glucagon at high plasma glucose levels exacerbates the hyperglycaemia caused by the lack of insulin [5]. The finding that mice remain normoglycaemic even after complete destruction of their beta cells if glucagon action is prevented [6] provides a spectacular demonstration of the contribution of glucagon to the hyperglycaemia seen in diabetes. 


\section{Regulation of glucagon secretion: intrinsic, paracrine or both?}

The metabolic regulation of glucagon secretion remains hotly debated. A central question is whether the alpha cells are capable of sensing changes in the plasma glucose levels by themselves ('intrinsic regulation') [7] or if they are regulated by factors released from neighbouring endocrine cells ('paracrine regulation') [8]. The fact that insulin and glucagon secretion are reciprocally regulated by glucose gave rise to the idea that glucagon secretion is under paracrine control by insulin (the 'switch-off' hypothesis) [9, 10]. The switch-off hypothesis is attractive as it provides a simple explanation for the hypersecretion of glucagon seen in diabetes (when insulin secretion is low) and why this is corrected by administration of exogenous insulin. Variations on this theme postulate that the inhibitory effect of high glucose on alpha cells is mediated by factors co-released with insulin from the beta cells (like $\gamma$-aminobutyric acid [GABA] [11], $\mathrm{Zn}^{2+}$ [12] or $\gamma$-hydroxybutyrate [GHB] [13]). In addition, there is strong evidence that glucagon secretion is under vagal regulation $[14,15]$.

However, a problem with the switch-off hypothesis is that glucagon secretion is almost maximally inhibited at glucose concentrations that do not stimulate insulin secretion [16]. This is highlighted by the data in Fig. 1, which summarises the time- and concentration-dependent effects of glucose on insulin and glucagon secretion measured in a perfused mouse pancreas preparation. Increasing the glucose concentration from 1 to $6 \mathrm{mmol} / 1$ reduced glucagon secretion by $60-70 \%$. It is notable that glucagon secretion remained equally

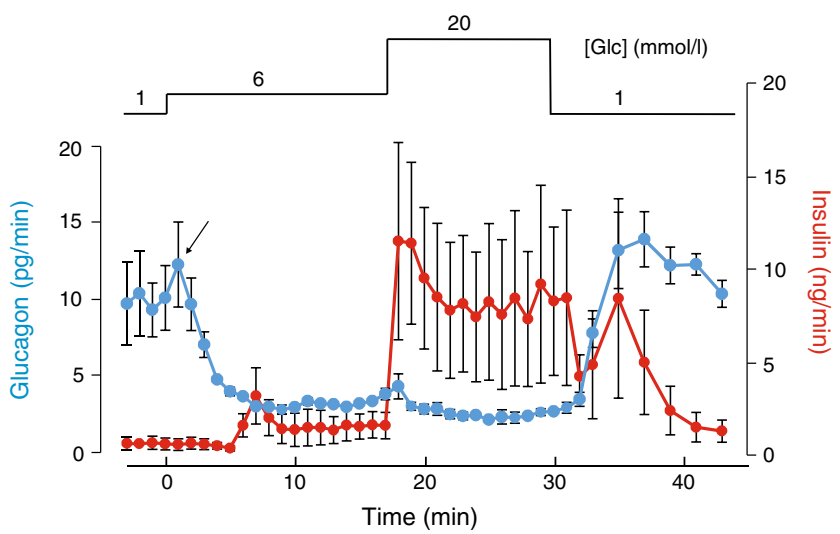

Fig. 1 Reciprocal effects of glucose on glucagon and insulin secretion. The pancreas was perfused via the aorta at physiological rate $\sim 0.3 \mathrm{ml} / \mathrm{min}$ [84] and in the normal direction and the effluent collected via the portal vein. Insulin secretion (red) was stimulated and glucagon secretion (blue) suppressed when the extracellular glucose concentration ([Glc]) was increased from 1 to 6 and then $20 \mathrm{mmol} / \mathrm{l}$. Note the transient stimulation of glucagon secretion when glucose was elevated (arrow), that inhibition of glucagon secretion is seen before any detectable stimulation of insulin secretion and prominent 'off response' in glucagon secretion when glucose was lowered from 20 to $1 \mathrm{mmol} / \mathrm{l}$ suppressed during the first and second phases of insulin secretion and that inhibition peaked before any detectable stimulation of insulin secretion. Moreover, increasing the glucose level from 6 to $20 \mathrm{mmol} / \mathrm{l}$ resulted in much stronger stimulation of insulin secretion (approximately tenfold higher than steady-state release at $6 \mathrm{mmol} / \mathrm{l}$ ) but this did not translate into further inhibition of glucagon secretion.

The dissociation between insulin signalling and glucagon secretion is also supported by the surprisingly mild effects on glucagon secretion observed following genetic ablation of the insulin receptors in the alpha cells $[17,18]$. The findings that glucose remains capable of inhibiting glucagon secretion in somatostatin-deficient islets [19] and in the presence of somatostatin receptor antagonists [20] also suggest that somatostatin released by the delta cells does not function as a 'switch-off' signal for glucagon release. Collectively, these data provide little evidence of a paracrine regulation of glucagon secretion by insulin at glucose concentrations at or below the threshold for stimulation of insulin or somatostatin release $(6 \mathrm{mmol} / \mathrm{l})$. However, we acknowledge that paracrine regulation may become functionally more significant at glucose concentrations associated with stronger stimulation of insulin or somatostatin secretion (or other factors released by the beta and delta cells). It should also be noted that isolated islets (when innervation has been severed) remain capable of responding to low glucose concentrations with stimulation of glucagon secretion.

\section{Pancreatic alpha cells are electrically excitable but regulation by glucose is obscure}

Like beta cells, alpha cells are electrically excitable. However, unlike beta cells, alpha cells fire action potentials [21-23] and exhibit spontaneous oscillations in intracellular $\mathrm{Ca}^{2+}$ concentrations $\left(\left[\mathrm{Ca}^{2+}\right]_{\mathrm{i}}\right)$ at low $(0-3 \mathrm{mmol} / \mathrm{l})$ glucose concentrations [24-26]. The occurrence of spontaneous electrical activity and $\left[\mathrm{Ca}^{2+}\right]_{\mathrm{i}}$ oscillations in alpha cells at low glucose levels is well established and explains why glucagon secretion is stimulated under hypoglycaemic conditions. However, the impact of higher glucose concentrations on glucagon secretion is more controversial. Some studies suggest that elevation of glucose levels hyperpolarises alpha cells [27] and lowers $\left[\mathrm{Ca}^{2+}\right]_{\mathrm{i}}$ [28-31]. Others have indicated that isolated alpha cells (obtained by fluorescence-activated cell sorting [FACS]) behave like beta cells, i.e. they are electrically silent with low $\left[\mathrm{Ca}^{2+}\right]_{i}$ at low glucose levels, but elevation of glucose triggers depolarisation, electrical activity and elevation of $\left[\mathrm{Ca}^{2+}\right]_{i}$ [32]. Finally, there are reports suggesting little effect of glucose on $\left[\mathrm{Ca}^{2+}\right]_{\mathrm{i}}$ in intact islets $[24,33]$. The latter finding has led to the proposal that the regulation of glucagon granule release may be exerted at a late stage in the alpha cell stimulus-secretion coupling, distal to the elevation of $\left[\mathrm{Ca}^{2+}\right]_{i}[34]$. 
The above summary may not be a comprehensive review of the literature, but the intention here is rather to highlight the great variability of the reported responses to glucose.

We have developed techniques that allow patch-clamp studies of freshly isolated intact islets [35]. Fig. 2 shows measurements of $\left[\mathrm{Ca}^{2+}\right]_{\mathrm{i}}$ and electrical activity from alpha cells using this preparation. Bursts of increased $\left[\mathrm{Ca}^{2+}\right]_{i}$ are present at $1 \mathrm{mmol} / \mathrm{l}$ glucose (when glucagon secretion is stimulated), but elevation of glucose to $6 \mathrm{mmol} / \mathrm{l}$, a maximally inhibitory concentration (see Fig. 1), is not associated with any detectable reduction of $\left[\mathrm{Ca}^{2+}\right]_{i}$ (Fig. 2a). Unexpectedly, elevation of glucose depolarised the alpha cell by $\sim 10 \mathrm{mV}$ and doubled the rate of action potential firing (Fig. 2b). In hormone release experiments in groups of isolated islets prepared the same way as those used for electrophysiology, $6 \mathrm{mmol} / \mathrm{l}$ glucose consistently inhibited glucagon secretion by $\sim 50 \%$ [26]. This effect is quantitatively similar to those observed in the perfused pancreas, suggesting that islet function was not compromised during isolation. Our in situ measurements of alpha cell electrical activity and $\left[\mathrm{Ca}^{2+}\right]_{\mathrm{i}}$ therefore suggest a dissociation between these processes and glucagon secretion. A possible resolution of this conundrum is outlined below.

\section{Metabolism-secretion coupling in alpha cells}

Glucose metabolism in glucagon-secreting alpha cells differs from that in beta cells in several important respects. First, glucose uptake is mediated by GLUT1 rather than GLUT2 [36]. Second, although alpha cells (like beta cells) express high- $K_{\mathrm{m}}$ glucokinase (GCK; hexokinase IV), they also express the low- $K_{\mathrm{m}}$ hexokinase II, which accounts for $\sim 50 \%$ of glucose phosphorylation in alpha cells vs $<10 \%$ in beta cells [37]. Third, whereas the rates of glucose utilisation (glycolysis + Krebs cycle) are comparable in alpha and beta cells [36], the rate of glucose oxidation (oxidative phosphorylation alone) in alpha cells is only $\sim 10 \%$ of that in beta cells [38]. Time-resolved but non-quantitative measurements of the cytoplasmic ATP concentration have revealed that elevation of glucose induces a prompt increase in ATP [26, 33]. Quantitative biochemical measurements of ATP and ADP in pure alpha and beta cell fractions further suggest that the ATP/ ADP ratio in alpha cells at $1 \mathrm{mmol} / \mathrm{l}$ glucose is as high as that in beta cells exposed to $6 \mathrm{mmol} / \mathrm{l}$ glucose [38].

It is interesting to correlate this information on alpha cell metabolism with the effects of various metabolic inhibitors on glucagon secretion. Thus, 3-O-methyl-D-glucose, a glucose analogue that is transported into the cell but not metabolised, does not influence glucagon secretion [19]. Mannoheptulose, an inhibitor of GCK, prevents the glucose-induced suppression of glucagon secretion [26]. The effects of mitochondrial inhibitors (such as oligomycin [26] and dinitrophenol [39]) are complex; in the presence of mitochondrial inhibitors,

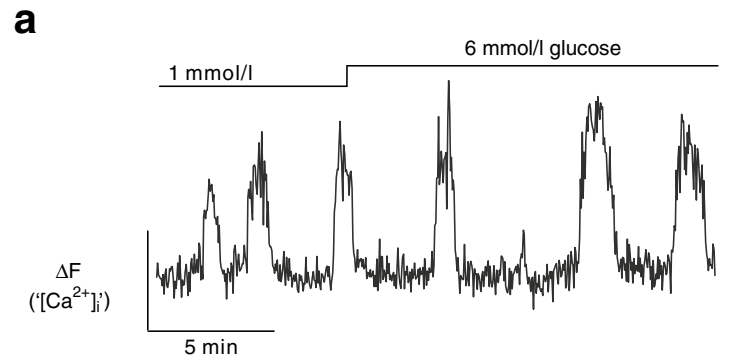

b

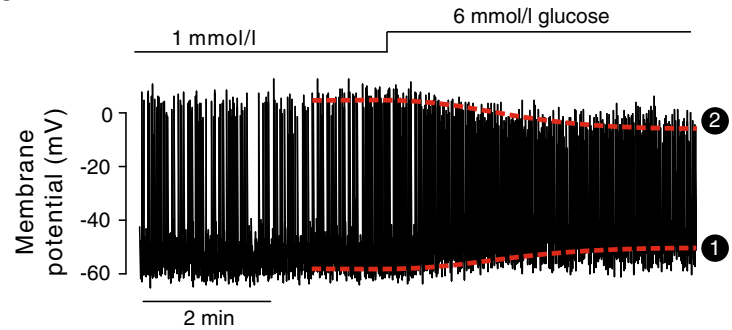

Fig. 2 Glucose inhibits glucagon release without affecting alpha cell electrical activity. (a-b) Effects of glucose on $\left[\mathrm{Ca}^{2+}\right]_{\mathrm{i}}(\mathbf{a})$ and electrical activity (b) in alpha cells in intact freshly isolated mouse pancreatic islets. Note in (a) the weak effect of glucose $(6 \mathrm{mmol} / \mathrm{l})$ on spontaneous $\left[\mathrm{Ca}^{2+}\right]_{\mathrm{i}}$ oscillations (reported as changes in fluo3 fluorescence $[\Delta \mathrm{F}]$; an upward deflection corresponds to an increase in $\left[\mathrm{Ca}^{2+}\right]_{\mathrm{i}}$ ). Note in $(\mathbf{b})$ that glucose ( $6 \mathrm{mmol} / \mathrm{l}$ ) depolarises the alpha cell by $\sim 10 \mathrm{mV}$ (dashed line (0) and decreases the height of action potentials by $\sim 10 \mathrm{mV}$ (dashed line (2)). Also note that alpha cells are spontaneously active at $1 \mathrm{mmol} / \mathrm{l}$ glucose in both (a) and (b). Data based on findings reported in [26]

glucagon secretion is stimulated at high glucose levels but inhibited at low glucose concentrations. Thus, alpha cells in which mitochondrial metabolism has been inhibited retain the ability to respond to glucose, albeit in the 'wrong' direction, raising the interesting possibility that glycolysis plays a more prominent regulatory role in glucagon secretion than in insulin secretion.

\section{Ion channels and islet cell electrical activity}

The electrophysiological properties of any given cell are determined by its ion channel complement. In this section we briefly outline how the different ion channels contribute to electrical activity in mouse and human alpha and beta cells.

Pancreatic beta cells exposed to low glucose are hyperpolarised $(-70 \mathrm{mV})$ and electrically silent. This is because the ATP-regulated $\mathrm{K}^{+}\left(\mathrm{K}_{\text {ATP }}\right)$ channel activity is very high ( $3 \mathrm{nS}$; corresponding to $\sim 300 \mathrm{~K}_{\mathrm{ATP}}$ channels being simultaneously active). When glucose is elevated to $>6 \mathrm{mmol} / \mathrm{l}, \mathrm{K}_{\text {ATP }}$ channel activity is reduced by $>75 \%$ and the cells depolarise. Importantly, $\mathrm{K}_{\mathrm{ATP}}$ channel closure alone is not sufficient to produce membrane depolarisation; a depolarising membrane current is also required [35]. Possible candidates include members of transient receptor potential (TRP) channel family (for a review, see [40]). The 
glucose-induced depolarisation leads to the activation of voltage-gated $\mathrm{Ca}^{2+}$ channels (principally dihydropyridinesensitive L-type $\mathrm{Ca}^{2+}$ channels) [41]. Activation of the L-type $\mathrm{Ca}^{2+}$ channels during action potential firing produces a localised increase in $\left[\mathrm{Ca}^{2+}\right]_{i}$ just below the plasma membrane and near the $\mathrm{Ca}^{2+}$ channels, which thereby triggers exocytosis of insulin granules, some of which may be physically tethered to the $\mathrm{Ca}^{2+}$ channels [42] Although there are several important electrophysiological differences between mouse and human beta cells, the fundamental aspects of glucose sensing are the same [43].

As already discussed, mouse alpha cells are electrically active at $1 \mathrm{mmol} / 1$ glucose and fire action potentials from a membrane potential of approx. $-55 \mathrm{mV}[26,44]$. The alpha cells are equipped with $\mathrm{K}_{\text {ATP }}$ channels of exactly the same type as those found in beta cells but their net activity is limited to $\sim 0.1 \mathrm{nS}$ (approximately eight simultaneously active channels). As a consequence of the low $\mathrm{K}_{\text {ATP }}$ channel activity, alpha cells have a very high input resistance (3-5 G $\Omega$ ) [26, 44]. This means currents as small as $1-2 \mathrm{pA}$ (equivalent to the current associated with openings of individual ion channels) will change the membrane potential by $3-10 \mathrm{mV}$. Thus, small changes in ion channel activity may have dramatic effects on membrane potential, action potential firing and glucagon secretion.

The upstroke of the action potential in mouse alpha cells is due to the opening of voltage-gated $\mathrm{Na}^{+}$channels [44]. During the peak of the action potential, voltage-gated $\mathrm{Ca}^{2+}$ channels activate. The magnitude of the $\mathrm{Ca}^{2+}$ current is only $\sim 15 \%$ of the $\mathrm{Na}^{+}$current $[45,46]$, and blocking the $\mathrm{Na}^{+}$channels exerts a strong inhibitory effect on both alpha cell electrical activity and glucagon secretion [26]. In mouse alpha cells, $70 \%$ of the $\mathrm{Ca}^{2+}$ current flows through L-type $\mathrm{Ca}^{2+}$ channels and only $\sim 20 \%$ is due to opening P/Q-type $\mathrm{Ca}^{2+}$ channels [26, 44]. Nevertheless, hormone release measurements using the $\mathrm{P} / \mathrm{Q}$-type $\mathrm{Ca}^{2+}$ channel inhibitor $\omega$-agatoxin ${ }^{1}$ indicate that the P/Q-type $\mathrm{Ca}^{2+}$ channels are particularly important for glucagon secretion evoked by low glucose concentrations [26]. In addition, mouse alpha cells express low-threshold T-type $\mathrm{Ca}^{2+}$ channels that may be involved in the initiation ('pace-making') of action potential firing [47, 48].

Increasing glucose to $\geq 6 \mathrm{mmol} / \mathrm{l}$ results in complete inhibition of the already low $\mathrm{K}_{\mathrm{ATP}}$ channel activity. As discussed above, this leads to a membrane depolarisation of $\sim 10 \mathrm{mV}$

\footnotetext{
${ }^{1}$ The non-L-type $\mathrm{Ca}^{2+}$ current component in mouse alpha cells was previously attributed to activation of $\omega$-conotoxin-sensitive $\mathrm{N}$-type $\mathrm{Ca}^{2+}$ channels. However, it was subsequently discovered that such channels are expressed at very low levels in alpha cells, whereas $\omega$-agatoxinsensitive $\mathrm{P} / \mathrm{Q}-$ type $\mathrm{Ca}^{2+}$ channels are highly expressed. Pharmacological experiments revealed that $\omega$-conotoxin had no effect on alpha cells $\mathrm{Ca}^{2+}$ currents in the presence of $\omega$-agatoxin. We therefore conclude that $\omega$ conotoxin unspecifically blocks P/Q-type $\mathrm{Ca}^{2+}$ channels in alpha cells. Here, non-L-type $\mathrm{Ca}^{2+}$ channels are therefore referred to as $\mathrm{P} / \mathrm{Q}$-type $\mathrm{Ca}^{2+}$ channels even when referred to as N-type in the original publications.
}

[26]. As in beta cells, this depolarisation requires a depolarising membrane current. The identity of this current in alpha cells remains unknown but a store-operated membrane conductance discussed below could potentially be involved. Crucially, elevation of glucose is not only associated with an increased rate of action potential firing, there is also a reduction in action potential height (Fig. 2). The latter effect occurs because the voltage-gated $\mathrm{Na}^{+}$channels underlying the upstroke undergo voltage-dependent inactivation and thereby become non-functional. At the most negative membrane potential, observed at $1 \mathrm{mmol} / \mathrm{l}$ glucose, $75 \%$ of the $\mathrm{Na}^{+}$channels remain available for activation. This decreases to $30 \%$ in the presence of $6 \mathrm{mmol} / \mathrm{l}$ glucose. The reduction in the proportion of $\mathrm{Na}^{+}$channels available for spike generation explains the lowered action potential amplitude. This is important because the P/Q-type $\mathrm{Ca}^{2+}$ channels that mediate the $\mathrm{Ca}^{2+}$ influx triggering glucagon exocytosis principally activate at the peak of the action potential.

Reactivation of the $\mathrm{Na}^{+}$channels occurs during the interval between two successive action potentials and the inter-spike membrane potential, which in turn is influenced by the number of voltage-dependent $\mathrm{K}^{+}$channels activated during the action potential; the stronger the activation of $\mathrm{K}^{+}$channels, the more negative the inter-spike membrane potential and the greater the reactivation of $\mathrm{Na}^{+}$channels. This may explain the paradox that blocking voltage-gated $\mathrm{K}^{+}$channels in alpha cells is associated with inhibition of glucagon secretion and electrical activity rather than the stimulation seen in beta cells [49-51].

Electrophysiologically, human alpha cells are almost identical to human beta cells $[51,52]$. Yet, glucose has opposite effects on insulin and glucagon secretion. Importantly, $\mathrm{K}_{\mathrm{ATP}}$ channel activity in isolated human alpha cells exposed to $1 \mathrm{mmol} / \mathrm{l}$ glucose is $75 \%$ lower than in beta cells under the same experimental conditions [51] and is in fact comparable to that in human beta cells exposed to insulin-releasing glucose concentrations, which probably explains the occurrence of spontaneous action potential firing in alpha cells under hypoglycaemic conditions. The net $\mathrm{K}_{\mathrm{ATP}}$ channel activity in human alpha cells (after subtraction of unspecific leak currents around the recording electrode) is equivalent to one $\mathrm{K}_{\mathrm{ATP}}$ channel being active at any time in the entire alpha cell. Such low $\mathrm{K}_{\text {ATP }}$ channel activities are not easily measured experimentally. However, the finding that the $\mathrm{K}_{\text {ATP }}$ channel blocker tolbutamide depolarised human alpha cells by $\sim 10 \mathrm{mV}$, reduced action potential height by $\sim 10 \mathrm{mV}$ [51] and inhibited glucagon secretion in human islets [16] indicates that even a $\mathrm{K}_{\text {ATP }}$ channel activity as low as this is sufficient to keep the alpha cell sufficiently repolarised to maintain action potential height and glucagon exocytosis. It remains to be demonstrated experimentally that glucose also reduces $\mathrm{K}_{\text {ATP }}$ channel activity in human alpha cells. Circumstantial evidence that glucose regulates glucagon secretion in human islets by 
closing $\mathrm{K}_{\text {АTP }}$ channels has been provided by the observation that the inhibitory effect of glucose on glucagon secretion can be reversed by low concentrations of the $\mathrm{K}_{\mathrm{ATP}}$ channel activator diazoxide $(2-3 \mu \mathrm{mol} / \mathrm{l})[16,26]$.

The key role of the $\mathrm{K}_{\text {ATP }}$ channels in the regulation of glucagon secretion is further illustrated by the strong reduction of glucagon secretion at low glucose concentrations and the (nearly complete) loss of glucose-induced suppression following genetic ablation of the $\mathrm{K}_{\mathrm{ATP}}$ channels $[16,19$, 53-55]. It has previously been reported that incubation of isolated mouse [56] and human islets [57] at high glucose concentrations $(>20 \mathrm{mmol} / \mathrm{l})$ results in a less effective inhibition of glucagon secretion than lower $(5-8 \mathrm{mmol} / \mathrm{l})$ glucose concentrations. Interestingly, in $\mathrm{K}_{\mathrm{ATP}}$ channel knockout mice, we found that increasing glucose stimulated glucagon secretion in a concentration-dependent manner. Thus, glucose appears to control glucagon secretion by both $\mathrm{K}_{\text {ATP }}$ channel-dependent (inhibition) and -independent (stimulation) processes (Fig. 3a). This is reminiscent of the situation in beta cells [58], with the important difference that the $\mathrm{K}_{\mathrm{ATP}}$ channel-dependent ('triggering') and -independent ('amplifying') effects on insulin secretion are both stimulatory (Fig. 3b), whereas they have opposing effects on glucagon secretion. The nature of the $\mathrm{K}_{\mathrm{ATP}}$ channel-independent stimulation of glucagon secretion remains to be elucidated, but it is noteworthy that glucose has been reported to amplify depolarisationevoked exocytosis in voltage-clamped rat alpha cells [32].

In addition to the $\mathrm{K}_{\mathrm{ATP}}$ channel-dependent mechanism for intrinsic glucose-induced inhibition of glucagon secretion we outline above, it has been postulated that glucose regulates glucagon secretion via a store-operated $\mathrm{Ca}^{2+}$ current flowing through Orail channels [28]. According to this hypothesis, elevation of glucose will activate the sarco-endoplasmic reticulum (sER) $\mathrm{Ca}^{2+}$-ATPase (SERCA). When the $\mathrm{Ca}^{2+}$ stores are filled, the Orail channels will be turned off, leading to alpha cell hyperpolarisation, cessation of action potential firing and suppression of glucagon secretion. The Orail-dependent mechanism has recently been reviewed elsewhere [59]. It is noteworthy that the $\mathrm{K}_{\mathrm{ATP}}$ channel- and Orail-dependent mechanisms for the intrinsic regulation of glucagon secretion predict opposite effects on the alpha cell membrane potential [60, 61]. Our data showing that glucose depolarises rather than repolarises the alpha cell are not consistent with a major role of Orail in glucagon secretion, but this does not exclude a modulatory role. Indeed, we have found that the SERCA inhibitor thapsigargin partially antagonises the inhibitory effect on glucagon secretion [62]. Further studies are required to determine the relative importance of the $\mathrm{K}_{\text {ATP }}$ channel and Orail-dependent regulation of glucagon secretion.
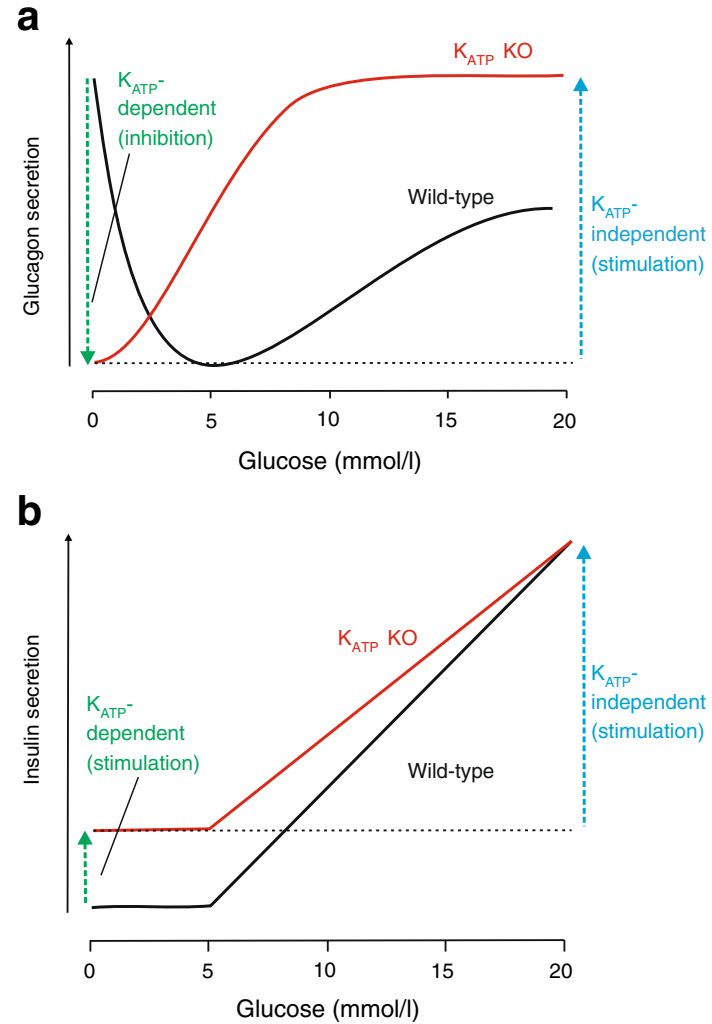

Fig. $3 \mathrm{~K}_{\text {ATP }}$ channel-dependent and -independent effects on insulin and glucagon secretion. (a) Effects of increasing glucose concentrations on glucagon secretion in wild-type and $\mathrm{K}_{\text {ATP }}$ channel knockout (Kir6.2 $2^{-/-}$) islets. In wild-type mice, increasing glucose from 0 to $5 \mathrm{mmol} / \mathrm{l}$ inhibits glucagon secretion, whereas higher glucose concentrations are less inhibitory. In islets lacking functional $\mathrm{K}_{\mathrm{ATP}}$ channels $\left(\mathrm{K}_{\mathrm{ATP}} \mathrm{KO}\right)$, increasing glucose results in a concentration-dependent stimulation of glucagon secretion. Thus, $\mathrm{K}_{\text {ATP }}$ channels mediate the inhibitory effect (green arrow left) and $\mathrm{K}_{\text {АTP }}$ channel-independent processes produce a stimulation of glucagon secretion (blue arrow right). In wild-type islets, the $\mathrm{K}_{\text {ATP }}$ channel-dependent processes superimpose, giving rise to the V-shaped concentration dependence of glucagon secretion. (b) As in (a) but comparing glucose-induced insulin secretion in wild-type and $\mathrm{K}_{\mathrm{ATP}}$ channel $\mathrm{KO}$ islets. In $\mathrm{K}_{\mathrm{ATP}}$ channel $\mathrm{KO}$ islets, basal insulin secretion is increased but the amplification at glucose concentrations $>5 \mathrm{mmol} / \mathrm{l}$ is intact. Note that the $\mathrm{K}_{\mathrm{ATP}}$ channel-dependent and -independent effects (green and blue arrows) both stimulate insulin secretion. Curves are based on data reported in [16]. Secretion rates have been normalised to maximum rate in the respective mouse strains

\section{Why does glucose stimulate insulin secretion but inhibit glucagon secretion?}

In alpha cells and beta cells, elevation of glucose produces membrane depolarisation and increases action potential frequency. Why then does glucose inhibit glucagon secretion whilst stimulating insulin secretion? There is a simple explanation to this conundrum, illustrated schematically in Fig. 4.

In beta cells, action potential firing and insulin secretion at low glucose concentrations are virtually zero. When glucose is elevated, glucose-induced electrical activity initiates insulin secretion from a very low basal level. Although the action 
a

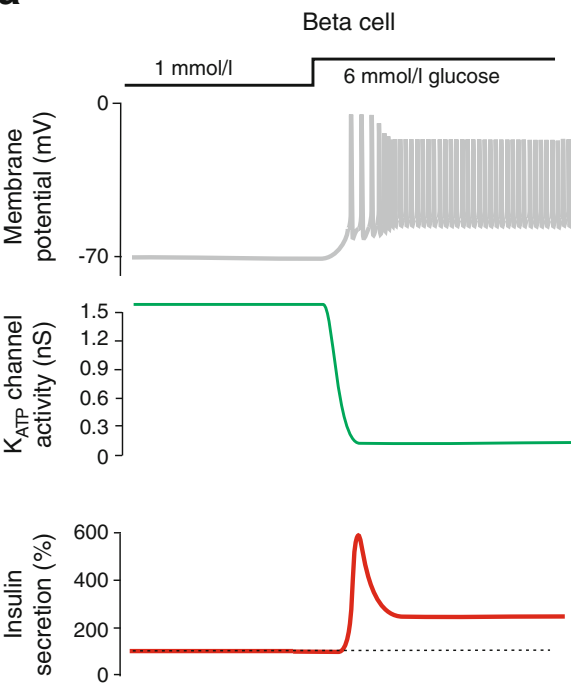

Fig. 4 Schematic representation of glucose-dependent effects on membrane potential/action potential firing and secretion in beta and alpha cells. (a) At low glucose, beta cells are hyperpolarised and electrically silent, because of high $\mathrm{K}_{\mathrm{ATP}}$ channel activity, and insulin secretion minimal. Increasing glucose results in $\mathrm{K}_{\text {ATP }}$ channel closure, membrane depolarisation and initiation of electrical activity and insulin secretion. During electrical activity, the amplitude of the action potentials declines. Because insulin granule exocytosis is steeply voltage-dependent, the decrease in action potential amplitude results in a reduction of insulin secretion. This may account for first (the initial bout of large-amplitude action potentials) and second phase insulin secretion (the steady-state firing of action potentials once the action potential amplitude has decreased to a new steady-state amplitude). Note that although insulin secretion declines as the action potential height is reduced, it remains

potential amplitude often undergoes a time-dependent decrease (leading to a gradual reduction of $\mathrm{Ca}^{2+}$-dependent exocytosis [43]), insulin secretion will remain much above basal levels even after this has occurred (Fig. 4a).

Under hypoglycaemic conditions, alpha cells generate large-amplitude $\mathrm{Na}^{+}$-dependent action potentials and this, via $\mathrm{Ca}^{2+}$ entry through $\mathrm{P} / \mathrm{Q}$-type $\mathrm{Ca}^{2+}$ channels, accounts for the high basal rate of glucagon secretion. As in beta cells, elevation of glucose leads to membrane depolarisation and an increased rate of action potential firing. However, the increase in action potential firing is fairly moderate and limited to an increase of $100 \%$. In addition to the effect on action potential frequency, as discussed above, glucose has another very important effect: it produces a reduction in action potential height, which results in diminished glucagon granule exocytosis. We estimate that the $10 \mathrm{mV}$ decrease in action potential amplitude we observe (Fig. 2b), via reduced P/Q-type $\mathrm{Ca}^{2+}$ channel activation, results in $80 \%$ inhibition of glucagon exocytosis. The associated increase in action potential frequency is insufficient to compensate for the much greater reduction of exocytosis. Combining these two effects it is predicted that glucose should inhibit glucagon secretion by b

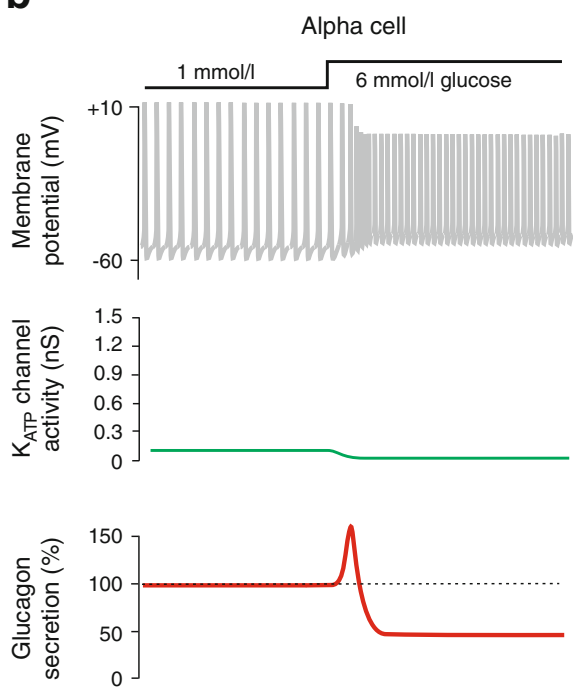

much higher than at low glucose (indicated by dashed line). (b) Because of low $\mathrm{K}_{\mathrm{ATP}}$ channel active, alpha cells are electrically active at low glucose concentrations and the resulting action potential firing is associated with stimulation of glucagon secretion. As in beta cells, increasing glucose leads to membrane depolarisation and an increased action potential firing in alpha cells that transiently stimulates glucagon secretion (see Fig. 1). Membrane depolarisation also leads to a reduction in action potential height that (because of steep voltage dependence of exocytosis) results in reduced glucagon secretion and, at steady-state, glucagon secretion at high glucose is lower than at low glucose. Thus, the membrane potential-induced reduction in exocytosis will result in net inhibition of glucagon secretion compared with that at low glucose (indicated by dashed line)

$\sim 60 \%$ (Fig. $4 \mathrm{~b}$ ), which is very close to the inhibition observed experimentally (see Fig. 1).

This scenario would also explain the paradox that in alpha cells glucose $(6 \mathrm{mmol} / \mathrm{l})$ has little effect on $\left[\mathrm{Ca}^{2+}\right]_{\mathrm{i}}$ whilst inhibiting glucagon secretion; the increase in action potential frequency leads to increased $\mathrm{Ca}^{2+}$ influx via L-type $\mathrm{Ca}^{2+}$ channels that partially compensates for the reduced activation of P/Q-type $\mathrm{Ca}^{2+}$ channels because of the lower action potential height on $\left[\mathrm{Ca}^{2+}\right]_{\mathrm{i}}$ (but not on glucagon secretion). Interestingly, stronger inhibitory effects on alpha cell $\left[\mathrm{Ca}^{2+}\right]_{\mathrm{i}}$ in intact islets have been reported at higher glucose concentrations $(11 \mathrm{mmol} / \mathrm{l})[16,30]$, possibly reflecting stronger paracrine suppression owing to greater stimulation of insulin and/or somatostatin release.

The capacity of glucagon-like peptide 1 (GLP-1) to inhibit glucagon secretion [63] has also been attributed to an intrinsic mechanism (but see [64] for an alternative paracrine viewpoint) that culminates in reduced activation of alpha cell $\mathrm{P} / \mathrm{Q}-$ type $\mathrm{Ca}^{2+}$ channels [65]. The latter effect is mediated by direct protein kinase A (PKA)-dependent inhibition of alpha cell $\mathrm{P} / \mathrm{Q}$-type $\mathrm{Ca}^{2+}$ channels [65] that is not secondary to changes in $\mathrm{K}_{\mathrm{ATP}}$ channel activity and membrane potential. 
The scenario outlined in Fig. 4 emphasises the importance of a high rate of action potential firing and consequential stimulation of glucagon secretion in alpha cells exposed to low glucose concentrations resulting from low resting $\mathrm{K}_{\mathrm{ATP}}$ channel activity. Importantly, the magnitude of the $\mathrm{K}_{\mathrm{ATP}}$ current that can be activated by wash-out of intracellular ATP is, if anything, larger in alpha cells than in beta cells [66]. Thus, the low $\mathrm{K}_{\mathrm{ATP}}$ channel activity in alpha cells is not due to low expression of the channel. Rather, $\mathrm{K}_{\mathrm{ATP}}$ channel activity must be under very strong tonic inhibition, possibly reflecting the high ATP/ADP ratio in alpha cells [38].

\section{Differential roles of $\mathrm{L}$ - and $\mathrm{P} / \mathrm{Q}$-type $\mathrm{Ca}^{2+}$ channels in mouse pancreatic alpha cells}

Both human and mouse alpha cells contain $\mathrm{P} / \mathrm{Q}$ as well as L-type voltage-gated $\mathrm{Ca}^{2+}$ channels $[44,51]$. In mouse islets, blocking the L-type $\mathrm{Ca}^{2+}$ channels has little effect on glucagon secretion evoked by low glucose. By contrast, blocking the
P/Q-type $\mathrm{Ca}^{2+}$ channel inhibits glucagon secretion as strongly as a maximally inhibitory glucose concentration [26, 51]. Thus, it appears that glucagon secretion evoked by low glucose is selectively triggered by $\mathrm{Ca}^{2+}$ entry via $\mathrm{P} / \mathrm{Q}-$ type $\mathrm{Ca}^{2+}$ channels $\left(20 \%\right.$ of the $\mathrm{Ca}^{2+}$ current) and that $\mathrm{Ca}^{2+}$ entry via $\mathrm{L}$-type $\mathrm{Ca}^{2+}$ channels $\left(70 \%\right.$ of the $\mathrm{Ca}^{2+}$ current) is seemingly unimportant in this context. How can this paradox be explained?

To address this question we used high-resolution capacitance measurements of exocytosis (Fig. 5a) [67]. In agreement with the glucagon secretion measurements, depolarisationevoked exocytosis in alpha cells is inhibited by $\omega$-agatoxin [26]. We found that depolarisations with a duration as short as $10 \mathrm{~ms}$, which is comparable to the duration of the alpha cell action potential, evoke significant exocytosis (Fig. 5b). Importantly, the intracellular diffusion of $\mathrm{Ca}^{2+}$ during such brief action potentials is very limited, so only glucagon granules situated in the immediate vicinity of the P/Q-type $\mathrm{Ca}^{2+}$ channels undergo exocytosis. This stimulation of exocytosis is mediated by $\mathrm{Ca}^{2+}$ binding a

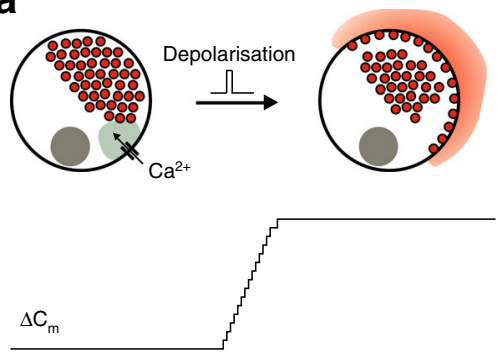

b

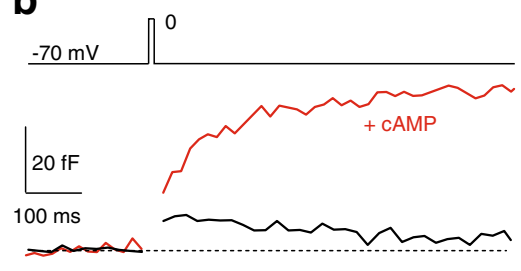

Fig. 5 Action potential height and $\mathrm{Ca}^{2+}$ channel activation in the control of glucagon exocytosis. (a) Schematic illustration of capacitance measurements. Exocytosis is associated with the addition of the granular membranes to the plasma membrane, resulting in an increased cell surface area (a). This can be detected as an increase in membrane capacitance $\left(\Delta \mathrm{C}_{\mathrm{m}}\right)$, which is proportionally related to the increase in cell surface area ( $\Delta \mathrm{SA}$ ); thus, $\Delta \mathrm{C}_{\mathrm{m}}=\varepsilon \times \Delta \mathrm{SA}$, where $\varepsilon$ is the specific capacitance $(10 \mathrm{fF} /$ $\mu \mathrm{m}^{2}$ ). Fusion of a glucagon granule (diameter: $0.2 \mu \mathrm{m}$ ) can be estimated to produce a capacitance increase of $\sim 2 \mathrm{fF}$ [85]. (b) Increase in membrane capacitance evoked by $10 \mathrm{~ms}$ depolarisation from $-70 \mathrm{mV}$ to $0 \mathrm{mV}$ in the absence (black trace) and presence (red trace) of $0.1 \mathrm{mmol} / 1 \mathrm{cAMP}$. Note the larger exocytotic response in the presence of cAMP and that $\Delta \mathrm{C}_{\mathrm{m}}$ continues to increase beyond the depolarisation. (c) Effects of blocking $\mathrm{P} / \mathrm{Q}$ - and L-type (see footnote 1) $\mathrm{Ca}^{2+}$ channels on glucagon secretion at $1 \mathrm{mmol} / 1$ glucose in the absence $(-)$ and presence $(+)$ of $5 \mu \mathrm{mol} / 1$

d
C
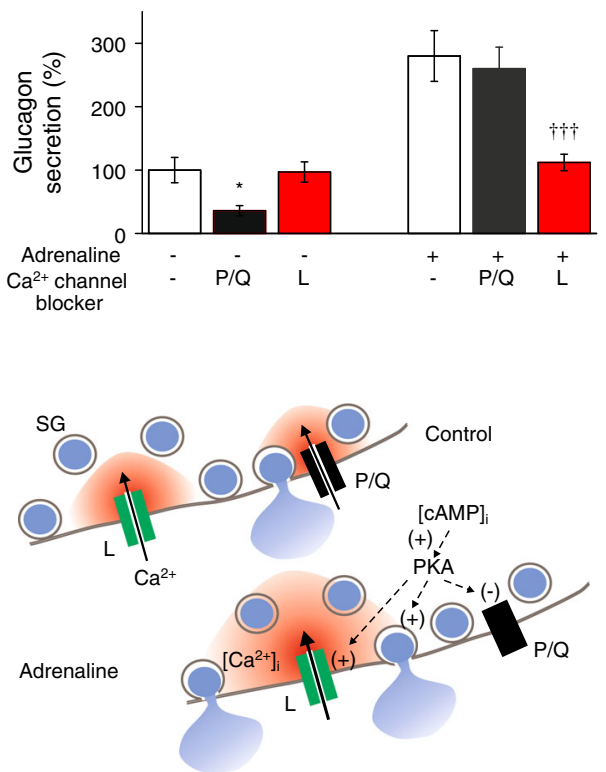

adrenaline as indicated. Data from [65]. ${ }^{* *} p<0.01 \mathrm{vs} 1 \mathrm{mmol} / \mathrm{l}$ glucose without adrenaline; ${ }^{\dagger \dagger} p<0.001 \mathrm{vs} 1 \mathrm{mmol} / 1$ glucose in the presence of adrenaline. Glucagon secretion rates are expressed as a per cent (\%) of that at $1 \mathrm{mmol} / 1$ glucose in the absence of adrenaline $(=100 \%)$. (d) Schematic representation of glucagon granule exocytosis evoked by low glucose alone and in the presence of adrenaline and the relationship to P/Q- and L-type $\mathrm{Ca}^{2+}$ channels. The shaded areas indicate 'active zones' around inner mouths of $\mathrm{Ca}^{2+}$ channels in which $\left[\mathrm{Ca}^{2+}\right]_{\mathrm{i}}$ rises to exocytotic levels. Via an increase in $[\mathrm{cAMP}]_{\mathrm{i}}$ and activation $(+)$ of PKA, adrenaline increases exocytosis due to $\mathrm{Ca}^{2+}$ influx via L-type $\mathrm{Ca}^{2+}$ channels by (1) inhibiting (-) P/Q-type $\mathrm{Ca}^{2+}$ channels, (2) increasing $\mathrm{Ca}^{2+}$ entry via L-type $\mathrm{Ca}^{2+}$ channels and (3) sensitising the exocytotic machinery to $\left[\mathrm{Ca}^{2+}\right]_{\mathrm{i}}$, thereby expanding the 'active zones' (as indicated by dashed arrows) 
to synaptotagmin-7, a $\mathrm{Ca}^{2+}$ sensor for exocytosis expressed in alpha cells [68].

What is the function of the L-type $\mathrm{Ca}^{2+}$ channels in mouse alpha cells? Clearly they are not involved in exocytosis evoked by action potential firing under hypoglycaemic conditions. However, when glucagon secretion is stimulated by adrenaline (epinephrine; acting via $\beta$-receptors), glucagon secretion becomes almost entirely reliant on L-type $\mathrm{Ca}^{2+}$ channels [21, 65] (Fig. 5c). Adrenaline depolarises the alpha cells by $\sim 10 \mathrm{mV}$ and reduces the action potential height by $>10 \mathrm{mV}$ [65]. Thus, the effects of adrenaline on electrical activity resemble those of glucose, and yet it stimulates rather than inhibits glucagon secretion. We believe that an adrenaline-induced increase in intracellular cAMP concentration $\left([\mathrm{cAMP}]_{\mathrm{i}}\right)[69]$ counteracts the impact of membrane depolarisation/reduced action potential height on glucagon secretion. Via activation of PKA, which is cAMPdependent, and the cAMP-sensor known as exchange protein directly activated by cAMP 2 (EPAC2), this increase in $[\mathrm{cAMP}]_{\mathrm{i}}$ culminates in (1) inhibition of $\mathrm{P} / \mathrm{Q}$-type $\mathrm{Ca}^{2+}$ channel activity, (2) stimulation of L-type $\mathrm{Ca}^{2+}$ channel activity, (3) mobilisation of $\mathrm{Ca}^{2+}$ from intracellular $\mathrm{Ca}^{2+}$ stores [28] and (4) sensitisation of exocytosis to $\left[\mathrm{Ca}^{2+}\right]_{i}[65]$. The combination of these effects accounts for the suppression of the P/Qtype $\mathrm{Ca}^{2+}$ channel-dependent component of glucagon secretion and concomitant enhancement of the L-type $\mathrm{Ca}^{2+}$ channel-dependent component. The latter effect is a consequence of the increased $\mathrm{Ca}^{2+}$ sensitivity of exocytosis which means that granules not immediately adjacent to the $\mathrm{P} / \mathrm{Q}$-type $\mathrm{Ca}^{2+}$ channels may also undergo release (Fig. 5d), accounting for a component of exocytosis that outlasts the duration of the depolarisation by $>100 \mathrm{~ms}$ (Fig. 5b).

\section{Glucagon secretion defects of diabetes recapitulated by small increases in $K_{\mathrm{ATP}}$ channel activity}

Diabetes has been referred to as a 'bihormonal disorder' [70, 71], involving both inadequate insulin secretion and defective glucagon secretion. The defects in glucagon secretion include over-secretion at high glucose (when it is not needed) and inadequate release at low glucose (when it is needed) [72, 73]. Of course, the concept of diabetes as a bihormonal disorder does not imply that the hormonal defects are limited to insulin and glucagon secretion. Defects of glucagon secretion, similar to those previously observed clinically in patients with type 2 diabetes, are also observed in isolated islets. Thus, glucagon secretion at low glucose levels tends to be reduced and at high glucose levels islets from diabetic donors release more glucagon than islets from non-diabetic donors (Fig. 6a). These fairly dramatic changes in glucagon secretion are correlated with a reduction of $\sim 30 \%$ in glucose-induced insulin secretion (Fig. 6b).
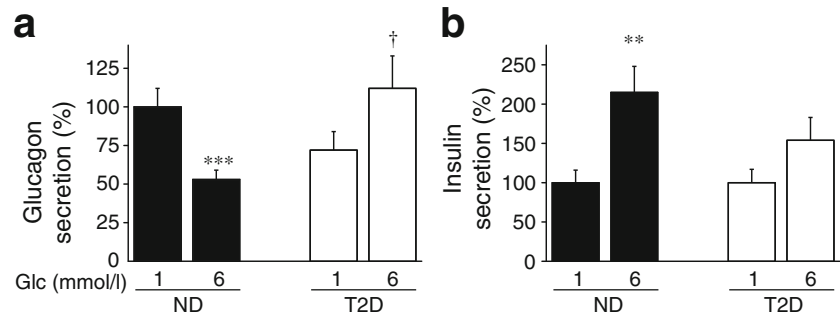

C

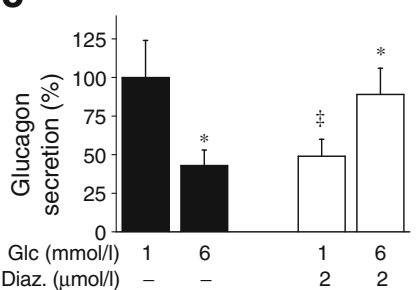

d

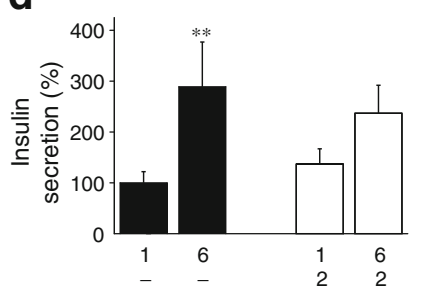

Fig. 6 Inverted regulation of glucagon secretion by glucose in diabetic islets recapitulated in non-diabetic islets following pharmacological activation of $\mathrm{K}_{\mathrm{ATP}}$ channels. Effects of increasing glucose from 1 to $6 \mathrm{mmol} / \mathrm{l}$ in islets from non-diabetic donors (ND) and type 2 diabetic (T2D) patients on glucagon (a) and insulin secretion (b). Glucagon (c) and insulin secretion (d) from isolated human islets from ND at 1 and $6 \mathrm{mmol} / \mathrm{l}$ glucose in the absence and presence of $2 \mu \mathrm{mol} / 1$ diazoxide. Secretion data are expressed as a per cent (\%) of that observed at $1 \mathrm{mmol} / 1$ glucose under control conditions (no test substances added; $=100 \%$ ) or in non-diabetic islets. ${ }^{*} p<0.05 ;{ }^{*} p<0.01 ; * * * p<0.001 \mathrm{vs} 1 \mathrm{mmol} / \mathrm{lglu}-$ cose under the same experimental conditions. ${ }^{\dagger} p<0.05$ vs $6 \mathrm{mmol} / \mathrm{l}$ glucose. ${ }^{\star} p<0.05$ vs $1 \mathrm{mmol} / 1$ glucose under control conditions. Data in (a) and (c) taken from [26]

Interestingly, the glucagon secretion defect associated with type 2 diabetes can be recapitulated by treating islets from non-diabetic donors with a low $(2 \mu \mathrm{mol} / \mathrm{l})$ concentration of the pharmacological $\mathrm{K}_{\mathrm{ATP}}$ channel activator diazoxide (Fig. 6c), an experimental condition that increases the whole-cell $\mathrm{K}_{\mathrm{ATP}}$ channel activity by as little as $\sim 100 \mathrm{pS}$ [26]. At this concentration, diazoxide does not have much effect on glucoseinduced insulin secretion (Fig. 6d and [16]) and somatostatin secretion [62]. In the presence of $2 \mu \mathrm{mol} / 1$ diazoxide, glucagon secretion is strongly reduced at low glucose concentrations and increasing the glucose concentration stimulates rather than inhibits glucagon secretion. These observations raise the exciting possibility that the inverted glucose regulation of glucagon secretion seen in type 2 diabetes may be a consequence of a minute increase in alpha cell $\mathrm{K}_{\mathrm{ATP}}$ channel activity. In this context it is also of interest that it has previously been reported that carriers of the activating $\mathrm{K}_{\mathrm{ATP}}$ channel variant E23K exhibit reduced suppression of glucagon secretion during hyperglycaemia [74].

An inverted glucagon secretion response to glucose was also seen in islets treated with oligomycin, an inhibitor of mitochondrial ATP synthase (Fig. 7a). In the presence of this mitochondrial inhibitor, glucagon secretion was reduced at low glucose concentrations and was stimulated rather than inhibited by elevated glucose levels. 
a

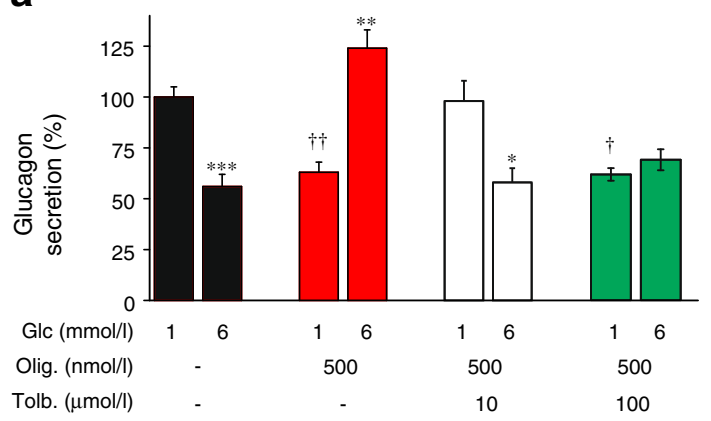

b

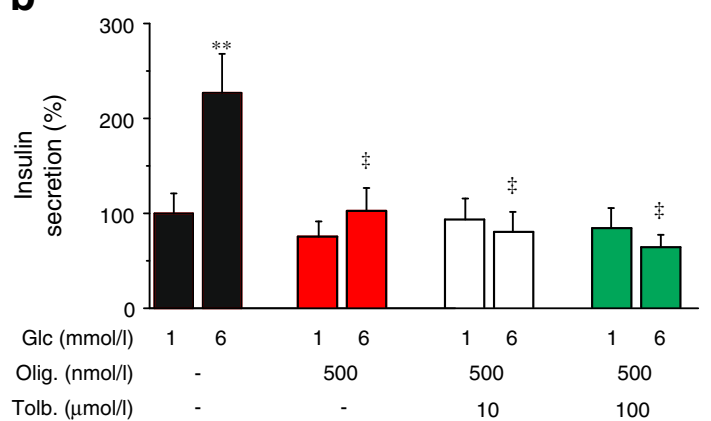

Fig. 7 Inverted regulation of glucagon secretion by glucose in metabolically compromised islets. Effects of glucose on glucagon (a) and insulin secretion (b) from isolated mouse islets at 1 and $6 \mathrm{mmol} / \mathrm{l}$ glucose (Glc) in the absence and presence of $500 \mathrm{nmol} / 1$ oligomycin (Olig.) and 10 or $100 \mu \mathrm{mol} / 1$ tolbutamide (Tolb.), as indicated. Secretion data are expressed as a per cent (\%) of that observed at $1 \mathrm{mmol} / \mathrm{l}$ glucose in the absence of oligomycin $(=100 \%) .{ }^{*} p<0.05 ; * * p<0.01 ; * * * p<0.001$ vs $1 \mathrm{mmol} / 1$ glucose under the same experimental conditions with the different experimental conditions indicated by the same colour bar fill; ${ }^{\dagger} p<0.05$; ${ }^{\dagger \dagger} p<0.01$ vs $1 \mathrm{mmol} / 1$ glucose under control conditions; ${ }^{t} p<0.05$ vs $20 \mathrm{mmol} / \mathrm{l}$ glucose. Some of the data in (a) are taken from [26]

Importantly, normal glucose regulation of glucagon secretion in such metabolically compromised islets could be restored by a low tolbutamide concentration $(10 \mu \mathrm{mol} / \mathrm{l})$ (Fig. 7a). When a tenfold higher concentration of tolbutamide was used $(100 \mu \mathrm{mol} / \mathrm{l})$, glucagon secretion was strongly inhibited, regardless of the glucose concentration. In oligomycin-treated islets, glucose failed to stimulate insulin secretion and tolbutamide was without stimulatory effect (Fig. 7b). Thus, the normalisation of glucagon secretion produced by tolbutamide cannot be attributed to increased insulin release.

These data suggest that the glucagon secretion defects associated with type 2 diabetes may be a consequence of increased $\mathrm{K}_{\mathrm{ATP}}$ channel activity in the alpha cell. If this is the case, then it should be possible to correct the glucagon secretion defect seen in islets from type 2 diabetic organ donors with tolbutamide. This is indeed the case, and we have recently reported that $10 \mu \mathrm{mol} / \mathrm{l}$ tolbutamide restores normal glucose regulation in islets from diabetic donors [26].
Understanding the glucagon secretion defects of diabetes

Figure 8 schematically summarises the regulation of electrical activity/glucagon secretion and how it depends on $\mathrm{K}_{\mathrm{ATP}}$ channel activity. In healthy alpha cells (Fig. 8a), $\mathrm{K}_{\mathrm{ATP}}$ channel activity at low glucose concentrations is very low but greater than 0 . Under these conditions, the alpha cell membrane potential is sufficiently depolarised to allow action potential firing but negative enough to prevent inactivation of the voltage-gated $\mathrm{Na}^{+}$channels. Thus, large-amplitude action potentials, associated with activation of P/Q-type $\mathrm{Ca}^{2+}$ channels and glucagon exocytosis, are generated.

When glucose levels are elevated, $K_{\text {ATP }}$ channels close and the alpha cell depolarises, which, as discussed above, results in voltage-dependent inactivation of the $\mathrm{Na}^{+}$channels, lowered action potential height and reduced activation of the $\mathrm{P} / \mathrm{Q}-$ type $\mathrm{Ca}^{2+}$ channels with resultant suppression of glucagon exocytosis.

Based on the experiments using low concentrations of diazoxide, we postulate that $\mathrm{K}_{\text {ATP }}$ channel activity is slightly higher $(+100 \%)$ in type 2 diabetic than in healthy alpha cells (Fig. 8b). The experiments with oligomycin suggest that this may be a consequence of impaired mitochondrial function. The increased $\mathrm{K}_{\mathrm{ATP}}$ channel activity leads to a more negative alpha cell membrane potential, so that action potential firing at low glucose concentrations is either reduced or completely suppressed and glucagon secretion is correspondingly reduced. Despite the impaired mitochondrial metabolism, an increase in glucose remains capable of elevating the intracellular ATP/ADP ratio sufficiently to partially close the $\mathrm{K}_{\mathrm{ATP}}$ channels. As a result, alpha cells depolarise, leading to increased action potential firing. This explains why glucagon secretion is stimulated rather than inhibited by glucose in type 2 diabetic islets. The electrophysiological and secretory responses shown here schematically have recently been substantiated by computational analyses [60].

It has been reported that the $\mathrm{Na}^{+}$current density in alpha cells from diabetic rats is twice as big as that in non-diabetic cells [75]. Such an effect might also contribute to the oversecretion of glucagon at high glucose in patients with type 2 diabetes. This is because even after the $\mathrm{Na}^{+}$channels have undergone partial voltage-dependent inactivation in response to glucose-induced depolarisation, remaining $\mathrm{Na}^{+}$channel activity would be sufficient to ensure continued generation of full size action potentials.

We have found that a low concentration of tolbutamide restores normal glucose regulation of glucagon secretion in islets from donors with type 2 diabetes. We used a concentration of $10 \mu \mathrm{mol} / \mathrm{l}$, which is close to the level that reduces $\mathrm{K}_{\text {ATP }}$ channel activity by $50 \%$ [76]. Thus, $\mathrm{K}_{\text {ATP }}$ channel activity in type 2 diabetic alpha cells exposed to tolbutamide is comparable to that seen in non-diabetic cells under hypoglycaemic conditions (Fig. 8c). Under these conditions, a further 
a

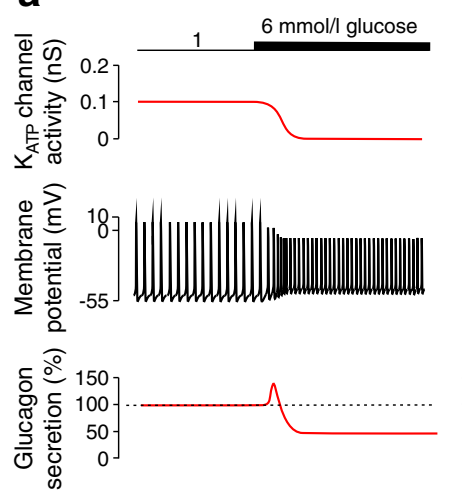

C
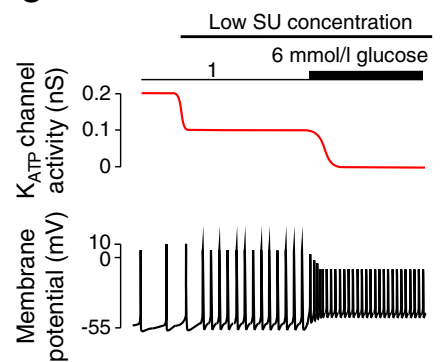

ㅇㅇㅇ 150

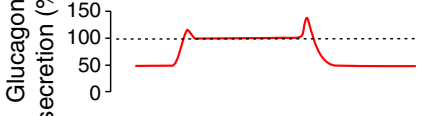

b
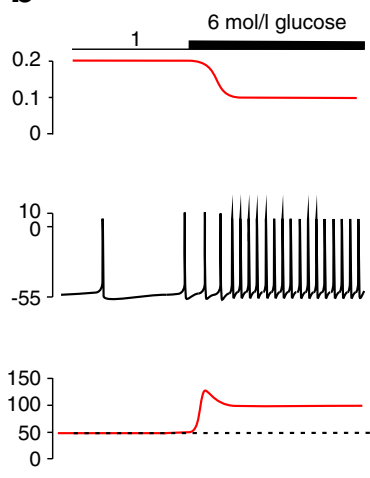

d
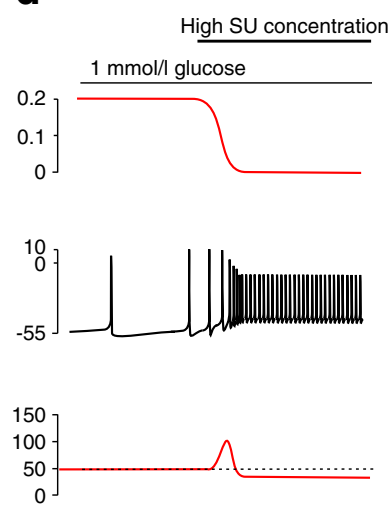

Fig. 8 Dual effects of $K_{\text {ATP }}$ channel activity on alpha cell electrical activity and glucagon secretion. (a) Schematic representation of the relationship between $\mathrm{K}_{\mathrm{ATP}}$ channel activity, electrical activity and glucagon secretion in non-diabetic alpha cell. Increasing glucose reduces net $\mathrm{K}_{\text {ATP }}$ channel activity from $0.1 \mathrm{nS}$ (equivalent to eight $\mathrm{K}_{\text {ATP }}$ channels being simultaneously active in the entire alpha cell) to $0 \mathrm{nS}$. This results in membrane depolarisation, reduced action potential height and inhibition of glucagon secretion. Dashed line indicates glucagon secretion at $1 \mathrm{mmol} / \mathrm{l}$ glucose. (b) As in (a) but depicting a type 2 diabetic alpha cell with a $\mathrm{K}_{\text {ATP }}$ channel activity was twice that in ND alpha cells (i.e. $0.2 \mathrm{nS}$ ). Type 2 diabetic alpha cells are partially repolarised and action potential frequency is reduced. Increasing glucose inhibits $\mathrm{K}_{\mathrm{ATP}}$ channel activity by $50 \%$, resulting in slight membrane depolarisation and increased action potential firing. Unlike the situation in non-diabetic alpha cells, the membrane potential remains sufficiently repolarised to prevent a (major) reduction of action potential height, and glucagon secretion is therefore stimulated. (c) As in (b) but a low concentration of sulfonylureas (SU) was added before elevation of glucose to block $50 \%$ of the $\mathrm{K}_{\text {ATP }}$ channels. This results in increased action potential firing and stimulation of glucagon secretion. Subsequent elevation of glucose is further reduction of $\mathrm{K}_{\text {ATP }}$ channel activity (down to $\sim 0 \mathrm{nS}$ ), strong membrane depolarisation, reduction of action potential height and inhibition of glucagon secretion. Dashed line indicates secretion at $1 \mathrm{mmol} / \mathrm{l}$ glucose in the presence of SU. (d) As in (a) but demonstrating effects of high SU concentrations. Addition of SU leads to complete inhibition of $\mathrm{K}_{\mathrm{ATP}}$ channel activity (from $0.2 \mathrm{nS}$ to $0 \mathrm{nS}$ ) with resultant strong depolarisation, reduction of action potential height and inhibition of glucagon secretion. Subsequent addition of glucose will have little (if any) further effect

reduction in $\mathrm{K}_{\text {ATP }}$ channel activity produced by glucose can be expected to result in strong membrane depolarisation, reduced action potential height $/ \mathrm{Ca}^{2+}$ entry and inhibition of glucagon secretion, similar to the responses in non-diabetic alpha cells (Fig. 8a).

These observations suggest that low concentrations of sulfonylureas may help to restore normal glucose regulation of glucagon secretion in diabetic patients - both an increase at low glucose and a reduction at high glucose. It is important, however, that the dose of sulfonylureas is carefully titrated. Figure $8 \mathrm{~d}$ explains schematically why this is the case. A high concentration of sulfonylureas will completely block $\mathrm{K}_{\mathrm{ATP}}$ channel activity in the diabetic alpha cell. This will be associated with strong membrane depolarisation, reduced action potential height and suppression of glucagon exocytosis even at low glucose concentrations, and subsequent elevations of glucose will exert no additive effect.

Sulfonylureas have previously been reported to inhibit glucagon secretion in vivo [77], and this was taken as an argument that glucagon secretion is suppressed by intra-islet insulin in a paracrine fashion. However, since sulfonylureas exert a direct effect on the alpha cells, it is equally likely that this effect reflects a direct effect mediated by closure of $\mathrm{K}_{\mathrm{ATP}}$ channels in the alpha cells.

In type 1 diabetes, it has been reported that sulfonylureas stimulate glucagon secretion [78-80]. This is reminiscent of what is observed in isolated rat alpha cells obtained by FACS. In these cells, $\mathrm{K}_{\text {ATP }}$ channel activity is increased $200 \%$ above that observed in alpha cells in freshly isolated intact mouse islets [32]. There is also evidence that alpha cells are reprogrammed following destruction of the beta cells [81]. It is possible that isolated alpha cells, as a consequence of the deprivation of factors released from beta cells (including insulin), have an increased $\mathrm{K}_{\mathrm{ATP}}$ channel activity. Indeed, nucleotides and $\mathrm{Ca}^{2+}$ co-released with insulin potentiate insulin secretion in an autocrine fashion mediated by $\mathrm{G}_{\mathrm{q}} / \mathrm{G}_{11}$ coupled receptors [82]. When this signalling was prevented by genetic ablation of $\mathrm{G}_{\mathrm{q}} / \mathrm{G}_{11}$, beta cell excitability was reduced via increased $\mathrm{K}_{\text {ATP }}$ channel activity. Similar mechanisms may become activated in alpha cells in type 1 diabetes or when alpha cells become separated from their beta cell neighbours, which would explain the observed increase in $\mathrm{K}_{\text {АTP }}$ channel activity that in turn explains why alpha cells adopt beta cell characteristics (such as being stimulated rather than inhibited by glucose or sulfonylureas).

\section{Coda}

Here we argue that glucagon secretion is determined by $\mathrm{K}_{\text {ATP }}$ channel activity and that glucose-induced closure of these channels translates into suppression of glucagon secretion. The concept that increased $\mathrm{K}_{\text {ATP }}$ channel activity may explain the inverted glucose response and the loss of appropriate counter-regulation in diabetic patients has obvious therapeutic implications. It should be relatively easy to conduct a clinical 
study on the potential usefulness of low concentrations of sulfonylureas (lower than those required to stimulate insulin secretion [83]) with a view to restoring normal glucose regulation of glucagon secretion. Sulfonylurea-based therapy targeting glucagon secretion may therefore be particularly relevant in insulin-treated type 1 diabetic patients and in patients with type 2 diabetes managed by diet and/or insulin sensitisers.

Acknowledgements We dedicate this review to the memory of our colleague Dr Matthias Braun (University of Alberta, Edmonton, AB, Canada) who unexpectedly died during the preparation of this manuscript and who made numerous important contributions to islet cell biology. We thank A. Clark (University of Oxford, Oxford, UK) for valuable and constructive critique and discussion.

Funding PR is a Wellcome Trust Senior Investigator. RR holds an RD Lawrence Fellowship awarded by Diabetes UK. Financial supported was also obtained from the European Foundation for the Study of Diabetes (EFSD) and the Medical Research Council (MRC). NJGR is an OXION Wellcome Trust DPhil student.

Duality of interest The authors declare that there is no duality of interest associated with this manuscript.

Contribution statement All authors are responsible for and contributed to the conception and design of the study, as well as the writing and editing of preliminary versions of the paper. All authors have approved the final version.

\section{References}

1. Cryer PE (1993) Glucose counterregulation: prevention and correction of hypoglycemia in humans. Am J Physiol 264:E149-E155

2. Gromada J, Franklin I, Wollheim CB (2007) Alpha-cells of the endocrine pancreas: 35 years of research but the enigma remains. Endocr Rev 28:84-116

3. Frayn KN (2010) Metabolic regulation: a human perspective. Wiley-Blackwell, Oxford

4. Gerich JE (1993) Control of glycaemia. Bailliere Clin Endocrinol Metab 7:551-586

5. Dunning BE, Foley JE, Ahren B (2005) Alpha cell function in health and disease: influence of glucagon-like peptide-1. Diabetologia 48: 1700-1713

6. Lee Y, Berglund ED, Wang MY et al (2012) Metabolic manifestations of insulin deficiency do not occur without glucagon action. Proc Natl Acad Sci U S A 109:14972-14976

7. Rorsman P, Salehi SA, Abdulkader F, Braun M, MacDonald PE (2008) $\mathrm{K}_{\mathrm{ATP}}$-channels and glucose-regulated glucagon secretion. Trends Endocrinol Metab 19:277-284

8. Unger RH, Orci L (2010) Paracrinology of islets and the paracrinopathy of diabetes. Proc Natl Acad Sci U S A 107:1600916012

9. Hope KM, Tran PO, Zhou H, Oseid E, Leroy E, Robertson RP (2004) Regulation of alpha-cell function by the beta-cell in isolated human and rat islets deprived of glucose: the "switch-off" hypothesis. Diabetes 53:1488-1495

10. Zhou H, Tran PO, Yang S et al (2004) Regulation of alpha-cell function by the beta-cell during hypoglycemia in Wistar rats: the "switch-off" hypothesis. Diabetes 53:1482-1487
11. Wendt A, Birnir B, Buschard K et al (2004) Glucose inhibition of glucagon secretion from rat alpha-cells is mediated by GABA released from neighboring beta-cells. Diabetes 53:1038-1045

12. Ishihara H, Maechler P, Gjinovci A, Herrera PL, Wollheim CB (2003) Islet beta-cell secretion determines glucagon release from neighbouring alpha-cells. Nat Cell Biol 5:330-335

13. Li C, Liu C, Nissim I et al (2013) Regulation of glucagon secretion in normal and diabetic human islets by $\gamma$-hydroxybutyrate and glycine. J Biol Chem 288:3938-3951

14. Miki T, Liss B, Minami K et al (2001) ATP-sensitive $\mathrm{K}^{+}$channels in the hypothalamus are essential for the maintenance of glucose homeostasis. Nat Neurosci 4:507-512

15. Lamy CM, Sanno H, Labouebe G et al (2014) Hypoglycemiaactivated GLUT2 neurons of the nucleus tractus solitarius stimulate vagal activity and glucagon secretion. Cell Metab 19:527-538

16. Macdonald PE, Marinis YZ, Ramracheya R et al (2007) A $K_{\text {ATP }}$ channel-dependent pathway within alpha cells regulates glucagon release from both rodent and human islets of Langerhans. PLoS Biol 5:e143

17. Gromada J, Duttaroy A, Rorsman P (2009) The insulin receptor talks to glucagon? Cell Metab 9:303-305

18. Kawamori D, Kurpad AJ, Hu J et al (2009) Insulin signaling in alpha cells modulates glucagon secretion in vivo. Cell Metab 9:350-361

19. Cheng-Xue R, Gomez-Ruiz A, Antoine N et al (2013) Tolbutamide controls glucagon release from mouse islets differently than glucose: involvement of $\mathrm{K}_{\text {ATP }}$ channels from both alpha-cells and delta-cells. Diabetes 62:1612-1622

20. Vieira E, Salehi A, Gylfe E (2007) Glucose inhibits glucagon secretion by a direct effect on mouse pancreatic alpha cells. Diabetologia 50:370-379

21. Gromada J, Bokvist K, Ding WG et al (1997) Adrenaline stimulates glucagon secretion in pancreatic A-cells by increasing the $\mathrm{Ca}^{2+}$ current and the number of granules close to the L-type $\mathrm{Ca}^{2+}$ channels. J Gen Physiol 110:217-228

22. Quoix N, Cheng-Xue R, Mattart L et al (2009) Glucose and pharmacological modulators of ATP-sensitive $\mathrm{K}^{+}$channels control $\left[\mathrm{Ca}^{2+}\right]_{\mathrm{c}}$ by different mechanisms in isolated mouse alpha-cells. Diabetes 58 : $412-421$

23. Rorsman P, Hellman B (1988) Voltage-activated currents in guinea pig pancreatic alpha 2 cells. Evidence for $\mathrm{Ca}^{2+}$-dependent action potentials. J Gen Physiol 91:223-242

24. Le Marchand SJ, Piston DW (2010) Glucose suppression of glucagon secretion: metabolic and calcium responses from alpha-cells in intact mouse pancreatic islets. J Biol Chem 285:14389-14398

25. Quoix N, Cheng-Xue R, Guiot Y, Herrera PL, Henquin JC, Gilon P (2007) The GluCre-ROSA26EYFP mouse: a new model for easy identification of living pancreatic alpha-cells. FEBS Lett 581:42354240

26. Zhang Q, Ramracheya R, Lahmann $C$ et al (2013) Role of $K_{\text {ATP }}$ channels in glucose-regulated glucagon secretion and impaired counterregulation in type 2 diabetes. Cell Metab 18:871-882

27. Manning Fox JE, Gyulkhandanyan AV, Satin LS, Wheeler MB (2006) Oscillatory membrane potential response to glucose in islet beta-cells: a comparison of islet-cell electrical activity in mouse and rat. Endocrinology 147:4655-4663

28. Liu YJ, Vieira E, Gylfe E (2004) A store-operated mechanism determines the activity of the electrically excitable glucagon-secreting pancreatic alpha-cell. Cell Calcium 35:357-365

29. Hjortoe GM, Hagel GM, Terry BR, Thastrup O, Arkhammar PO (2004) Functional identification and monitoring of individual alpha and beta cells in cultured mouse islets of Langerhans. Acta Diabetol 41:185-193

30. Quesada I, Todorova MG, Alonso-Magdalena P et al (2006) Glucose induces opposite intracellular $\mathrm{Ca}^{2+}$ concentration oscillatory patterns in identified alpha- and beta-cells within intact human islets of Langerhans. Diabetes 55:2463-2469 
31. Nadal A, Quesada I, Soria B (1999) Homologous and heterologous asynchronicity between identified alpha-, beta- and delta-cells within intact islets of Langerhans in the mouse. J Physiol 517:85-93

32. Olsen HL, Theander S, Bokvist K, Buschard K, Wollheim CB, Gromada J (2005) Glucose stimulates glucagon release in single rat alpha-cells by mechanisms that mirror the stimulus-secretion coupling in beta-cells. Endocrinology 146:4861-4870

33. Ravier MA, Rutter GA (2005) Glucose or insulin, but not zinc ions, inhibit glucagon secretion from mouse pancreatic alpha-cells. Diabetes 54:1789-1797

34. Le Marchand SJ, Piston DW (2012) Glucose decouples intracellular $\mathrm{Ca}^{2+}$ activity from glucagon secretion in mouse pancreatic islet alpha-cells. PLoS One 7:e47084

35. Rorsman P, Eliasson L, Kanno T, Zhang Q, Göpel S (2011) Electrophysiology of pancreatic beta-cells in intact mouse islets of Langerhans. Prog Biophys Mol Biol 107:224-235

36. Heimberg H, de Vos A, Pipeleers D, Thorens B, Schuit F (1995) Differences in glucose transporter gene expression between rat pancreatic alpha- and beta-cells are correlated to differences in glucose transport but not in glucose utilization. J Biol Chem 270:8971-8975

37. Heimberg H, de Vos A, Moens K et al (1996) The glucose sensor protein glucokinase is expressed in glucagon-producing alpha-cells. Proc Natl Acad Sci U S A 93:7036-7041

38. Detimary P, Dejonghe S, Ling Z, Pipeleers D, Schuit F, Henquin JC (1998) The changes in adenine nucleotides measured in glucosestimulated rodent islets occur in beta cells but not in alpha cells and are also observed in human islets. J Biol Chem 273:33905-33908

39. Ostenson CG, Agren A, Andersson A (1980) Effects of metabolic inhibitors on the regulation of pancreatic glucagon release. Biochim Biophys Acta 628:152-160

40. Colsoul B, Vennekens R, Nilius B (2011) Transient receptor potential cation channels in pancreatic beta cells. Rev Physiol Biochem Pharmacol 161:87-110

41. Schulla V, Renstrom E, Feil R et al (2003) Impaired insulin secretion and glucose tolerance in beta cell-selective $\mathrm{Ca}_{\mathrm{v}} 1.2 \mathrm{Ca}^{2+}$ channel null mice. EMBO J 22:3844-3854

42. Wiser O, Trus M, Hernandez A et al (1999) The voltage sensitive Lc-type $\mathrm{Ca}^{2+}$ channel is functionally coupled to the exocytotic machinery. Proc Natl Acad Sci U S A 96:248-253

43. Rorsman P, Braun M (2013) Regulation of insulin secretion in human pancreatic islets. Annu Rev Physiol 75:155-179

44. Barg S, Galvanovskis J, Göpel SO, Rorsman P, Eliasson L (2000) Tight coupling between electrical activity and exocytosis in mouse glucagon-secreting alpha-cells. Diabetes 49:1500-1510

45. Göpel SO, Kanno T, Barg S, Rorsman P (2000) Patch-clamp characterisation of somatostatin-secreting $\delta$-cells in intact mouse pancreatic islets. J Physiol 528:497-507

46. Göpel SO, Kanno T, Barg S, Weng XG, Gromada J, Rorsman P (2000) Regulation of glucagon release in mouse cells by $\mathrm{K}_{\text {ATP }}$ channels and inactivation of TTX-sensitive $\mathrm{Na}^{+}$channels. J Physiol 528:509-520

47. Leung YM, Ahmed I, Sheu L, Tsushima RG, Diamant NE, Gaisano HY (2006) Two populations of pancreatic islet alpha-cells displaying distinct $\mathrm{Ca}^{2+}$ channel properties. Biochem Biophys Res Commun 345:340-344

48. Huang YC, Rupnik M, Gaisano HY (2011) Unperturbed islet alphacell function examined in mouse pancreas tissue slices. J Physiol 589: 395-408

49. Spigelman AF, Dai X, MacDonald PE (2010) Voltage-dependent $\mathrm{K}^{+}$ channels are positive regulators of alpha cell action potential generation and glucagon secretion in mice and humans. Diabetologia 53: 1917-1926

50. Braun M, Rorsman P (2010) The glucagon-producing alpha cell: an electrophysiologically exceptional cell. Diabetologia 53:1827-1830

51. Ramracheya R, Ward C, Shigeto M et al (2010) Membrane potentialdependent inactivation of voltage-gated ion channels in alpha-cells inhibits glucagon secretion from human islets. Diabetes 59:21982208

52. Braun M, Ramracheya R, Bengtsson M et al (2008) Voltage-gated ion channels in human pancreatic beta-cells: electrophysiological characterization and role in insulin secretion. Diabetes 57:1618-1628

53. Gromada J, Ma X, Hoy M et al (2004) ATP-sensitive $\mathrm{K}^{+}$channeldependent regulation of glucagon release and electrical activity by glucose in wild-type and SUR $1^{-/-}$mouse alpha-cells. Diabetes 53(Suppl 3):S181-S189

54. Shiota C, Rocheleau JV, Shiota M, Piston DW, Magnuson MA (2005) Impaired glucagon secretory responses in mice lacking the type 1 sulfonylurea receptor. Am J Physiol Endocrinol Metab 289: E570-E577

55. Munoz A, Hu M, Hussain K, Bryan J, Aguilar-Bryan L, Rajan AS (2005) Regulation of glucagon secretion at low glucose concentrations: evidence for adenosine triphosphate-sensitive potassium channel involvement. Endocrinology 146:5514-5521

56. Salehi A, Vieira E, Gylfe E (2006) Paradoxical stimulation of glucagon secretion by high glucose concentrations. Diabetes 55:23182323

57. Braun M, Ramracheya R, Bengtsson M et al (2010) $\gamma$-Aminobutyric acid (GABA) is an autocrine excitatory transmitter in human pancreatic beta-cells. Diabetes 59:1694-1701

58. Henquin JC (2000) Triggering and amplifying pathways of regulation of insulin secretion by glucose. Diabetes 49:17511760

59. Gylfe E, Gilon P (2014) Glucose regulation of glucagon secretion. Diabetes Res Clin Pract 103:1-10

60. Fridlyand LE, Philipson LH (2012) A computational systems analysis of factors regulating alpha cell glucagon secretion. Islets 4:262283

61. Watts M, Sherman A (2014) Modeling the pancreatic alpha-cell: dual mechanisms of glucose suppression of glucagon secretion. Biophys $\mathbf{J}$ 106:741-751

62. Zhang Q, Bengtsson M, Partridge C et al (2007) R-type $\mathrm{Ca}^{2+}$-channel-evoked CICR regulates glucose-induced somatostatin secretion. Nat Cell Biol 9:453-460

63. Hare KJ, Vilsboll T, Asmar M, Deacon CF, Knop FK, Holst JJ (2010) The glucagonostatic and insulinotropic effects of glucagon-like peptide 1 contribute equally to its glucose-lowering action. Diabetes 59: $1765-1770$

64. de Heer J, Rasmussen C, Coy DH, Holst JJ (2008) Glucagon-like peptide-1, but not glucose-dependent insulinotropic peptide, inhibits glucagon secretion via somatostatin (receptor subtype 2 ) in the perfused rat pancreas. Diabetologia 51:2263-2270

65. De Marinis YZ, Salehi A, Ward CE et al (2010) GLP-1 inhibits and adrenaline stimulates glucagon release by differential modulation of $\mathrm{N}$ - and L-type $\mathrm{Ca}^{2+}$ channel-dependent exocytosis. Cell Metab 11: $543-553$

66. Bokvist K, Olsen HL, Hoy M et al (1999) Characterisation of sulphonylurea and ATP-regulated $\mathrm{K}^{+}$channels in rat pancreatic A-cells. Pflugers Arch - Eur J Physiol 438:428-436

67. Rorsman P, Renstrom E (2003) Insulin granule dynamics in pancreatic beta cells. Diabetologia 46:1029-1045

68. Gustavsson N, Wei SH, Hoang DN et al (2009) Synaptotagmin-7 is a principal $\mathrm{Ca}^{2+}$ sensor for $\mathrm{Ca}^{2+}$-induced glucagon exocytosis in pancreas. J Physiol 587:1169-1178

69. Tian G, Sandler S, Gylfe E, Tengholm A (2011) Glucose- and hormone-induced cAMP oscillations in alpha- and beta-cells within intact pancreatic islets. Diabetes 60:1535-1543

70. Unger RH (1976) Glucagon and insulin: a bihormonal system. Compr Ther 2:20-26

71. Unger RH, Orci L (1975) The essential role of glucagon in the pathogenesis of diabetes mellitus. Lancet 1:14-16

72. Cryer PE (2002) Hypoglycaemia: the limiting factor in the glycaemic management of type I and type II diabetes. Diabetologia 45:937-948 
73. Unger RH, Cherrington AD (2012) Glucagonocentric restructuring of diabetes: a pathophysiologic and therapeutic makeover. J Clin Invest 122:4-12

74. Tschritter O, Stumvoll M, Machicao F et al (2002) The prevalent Glu23Lys polymorphism in the potassium inward rectifier 6.2 (KIR6.2) gene is associated with impaired glucagon suppression in response to hyperglycemia. Diabetes 51:2854-2860

75. Huang YC, Rupnik MS, Karimian N et al (2013) In situ electrophysiological examination of pancreatic alpha cells in the streptozotocininduced diabetes model, revealing the cellular basis of glucagon hypersecretion. Diabetes 62:519-530

76. Trube G, Rorsman P, Ohno-Shosaku T (1986) Opposite effects of tolbutamide and diazoxide on the ATP-dependent $\mathrm{K}^{+}$channel in mouse pancreatic beta-cells. Pflugers Arch - Eur J Physiol 407: 493-499

77. Banarer S, McGregor VP, Cryer PE (2002) Intraislet hyperinsulinemia prevents the glucagon response to hypoglycemia despite an intact autonomic response. Diabetes 51:958-965

78. Cooperberg BA, Cryer PE (2009) Beta-cell-mediated signaling predominates over direct alpha-cell signaling in the regulation of glucagon secretion in humans. Diabetes Care 32:2275-2280

79. Bohannon NV, Lorenzi M, Grodsky GM, Karam JH (1982) Stimulatory effects of tolbutamide infusion on plasma glucagon in insulin-dependent diabetic subjects. J Clin Endocrinol Metab 54: 459-462

80. Ostergard T, Degn KB, Gall MA et al (2004) The insulin secretagogues glibenclamide and repaglinide do not influence growth hormone secretion in humans but stimulate glucagon secretion during profound insulin deficiency. J Clin Endocrinol Metab 89:297-302

81. Thorel F, Nepote V, Avril I et al (2010) Conversion of adult pancreatic alpha-cells to beta-cells after extreme beta-cell loss. Nature 464: $1149-1154$

82. Sassmann A, Gier B, Grone HJ, Drews G, Offermanns S, Wettschureck N (2010) The Gq/G11-mediated signaling pathway is critical for autocrine potentiation of insulin secretion in mice. J Clin Invest 120:2184-2193

83. Ishiyama N, Ravier MA, Henquin JC (2006) Dual mechanism of the potentiation by glucose of insulin secretion induced by arginine and tolbutamide in mouse islets. Am J Physiol Endocrinol Metab 290: E540-E549

84. Carlsson PO, Andersson A, Jansson L (1998) Influence of age, hyperglycemia, leptin, and NPY on islet blood flow in obesehyperglycemic mice. Am J Physiol 275:E594-E601

85. Göpel S, Zhang Q, Eliasson L et al (2004) Capacitance measurements of exocytosis in mouse pancreatic alpha-, beta- and delta-cells within intact islets of Langerhans. J Physiol 556:711-726 